\title{
P 85
}

\section{法改正後の産業医活動の現状と課題 その2}

○川田久美*1 武田則昭*1 影山 浩*2 氏家睦夫*3

$(* 1$ 香川医科大学医療管理学 $* 2$ 香川産業保健推進センター *3医療法人自生会氏家内科医院)

【はじは】労働安全衛生法（安衛法）の改正により、 産業医は専門的知識を身につけた上での産業医の職務、 つまり、産業医の専門性が一層求められることになって いる。加えて、産業医と現場の産業保健関係者とでは立 場がそれぞれ異なることもあり、産業保健活動に関して も種々の状況や問題点が窥われる。そこで、発表者らは、 A県における産業保健の現状を鑑み、法改正後の産業医 活動の現状や課題について、産業医サイドと事業所等現 場サイド（産業看護職、事業所関係者）の両面から調查 したので、その一部を報告する。

【対象と方法】今回の対象と方法については、本学会抄 録集の「その1」に示した。

質問項目は「その1」に示したが、「その2」では法 改正後の産業医活動の現状、今後の産業医活動、産業医 活動による事業所のメリット、ディメリットを中心に検 討したので、その一部を報告する。

【結果と考察】1.街生委員会への出席状況：「はい」 は産業医 $47.3 \%$ 、産業看護職 $90.7 \%$ 、事業所関係者 $87.2 \%$ と産業医で低かった。衛生委員会で話し合われた内容 (表 1、複数回答）：作業環境改善付産業医 $38.5 \%$ 、産業看護 職 $53.1 \%$ 、事業所関係者 $75.6 \%$ と産業医で低かった。作業 法改善は産業医 $17.3 \%$ 、産業看護職 $20.4 \%$ 、事業所関係者 $53.7 \%$ と産業医と産業看護職で低かった。㺪久等夘ル人久 竹は産業医 $36.5 \%$ 、産業看護職 $30.6 \%$ 、事業所関係者 14.6 \%と事業所関係者で低かった。健康づくりは産業医 $46.2 \%$ 、 産業看護職 $75.5 \%$ 、事業所関係者 $50.0 \%$ と産業看護職で高 かった。安全対策は産業医 $21.2 \%$ 、産業看護職 $30.6 \%$ 、事 業所関係者 $54.9 \%$ と事業所関係者で高かった。上記以外

\section{表 1 衛生委員会で話し合われた内容(複数回答)}

\begin{tabular}{|c|c|c|c|}
\hline & 產業医 & 看護職 & 事業所 \\
\hline わかららな & 0.0 & 2.0 & \\
\hline 健康診䉼 & 65.4 & 73.5 & 86.6 \\
\hline 健康・徫生教育 & 65.4 & 61.2 & 46.3 \\
\hline 健筆相談 & 59.6 & 44.9 & 36.6 \\
\hline 職場巡視 & 67.3 & 63.3 & 70.7 \\
\hline 作業環璄改善 & 38.5 & 53.1 & 75.6 \\
\hline 作军方法改善. & 17.3 & 20.4 & 53.7 \\
\hline 健康保持増進対策 & 17.3 & 26.5 & 12.2 \\
\hline 健康障害原因調真. & 1.9 & 8.2 & 4.9 \\
\hline 外部委託健詮機關選択・評価 & 17.3 & 4.1 & 9.8 \\
\hline 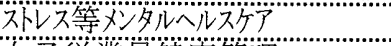 & 36.5 & 30.6 & 14.6 \\
\hline 㚣子焦業賞健康管理 & 11.5 & 4.1 & 9.8 \\
\hline 快適職場づくり & 25.0 & 32.7 & 48.8 \\
\hline 健康3゙<0 & 46.2 & 75.5 & 50.0 \\
\hline 高藏領策 & 5.8 & 4.1 & 13.4 \\
\hline 過労死 & 7.7 & 8.2 & 2.4 \\
\hline 安全対策 & 21.2 & 30.6 & 54.9 \\
\hline 常勤溥外菜冝健康管理 & 7.7 & 8.2 & 9.8 \\
\hline 艺の他 & 0.0 & 0.0 & 1.2 \\
\hline
\end{tabular}

の事項については、概ね 3 者で同様の傾向のものが多か った。総じては、作業環境や環境管理については、事業 所関係者が他の 2 者に比して高い傾向にあった。一方、 健康管理等については、逆の結果であつた。未開催理由 (産業看護職、事業所関係者) は時間的問題、経営者の 理解不足、人手問題が主たるものであった。未出席理由 （産業医）は案内がない $87.5 \%$ 、時間的余裕がない 17.9 \%が主たるものであった。2. 産業医活動 : 満足の状況 は、満足している、不満足であるはいずれも産業医と産 業看護職は事業所関係者とは異なる傾向であった。現在 の重点課題（複数回答）は、総じては同様の傾向であっ たが、わからないが産業医に高く、健康診断が産業医で 低い、職場巡視が産業看護職で高いなど若干の違いがみ られた。今後の重点課題 (表 2 、複数回答) は、総じて は同様の傾向であったが、健康診断・健康相談が産業看 護職で低く、職場巡視・健康保持増進・㺪々等犳多ル几欢 アが産業看護職で高いなど若干の違いがみられた。3. 産業医活動によるメリット（複数回答）：3者とも従業 員の健康向上、従業員の健康把握が可能、職場環境の改 善の順に高く同様の傾向であったが、それらより割合の 低い項目では、産業医、産業看護職は医療費削減、わか らない、企業イメージアップの順、事業所関係者は生産性向 上、休業日数減少、医療費削減で若干の違いがみられた。 4、産菜医活動によるデ イ州：産業医はわからない、 時間的負担増加、経済的負担増加の順、産業看護職は経 済的負担増加、わからない、時間的負担増加の順、事業 所関係者はわからない、経済的負担増加、時間的負担増 加の順でそれぞれ異なる傾向であった。

\section{表2 今後の重点課題(複数回答)}

\begin{tabular}{|c|c|c|c|}
\hline & 座業医 & 看護職 & 事業所 \\
\hline 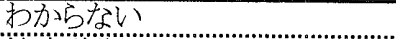 & 6.8 & 2.0 & 4.7 \\
\hline 健康診断。 & 35.6 & 13.7 & 32.6 \\
\hline 湕康・徫等教同 & 37.1 & 37.3 & 41.9 \\
\hline 箻殔相談 & 40.2 & 19.6 & 41.9 \\
\hline 職場巡視 & 18.9 & 37.3 & 17.4 \\
\hline 作業環璄改罍. & 14.4 & 17.6 & 15.1 \\
\hline 作業方法改壋. & 2.3 & 11.8 & 4.7 \\
\hline 健嫝保持壃進詨策 & 20.5 & 47.1 & 27.9 \\
\hline 煡萐蔁害原因調植 & 3.0 & 11.8 & 8.1 \\
\hline 外部委託健診機関選択・評俩 & 1.5 & 9.8 & 4.7 \\
\hline 䄭レス等犳多ヘルスケア & 23.5 & 45.1 & 32.6 \\
\hline 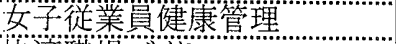 & 4.5 & 5.9 & 4.7 \\
\hline 快適職場 $3<b$ & 9.8 & 29.4 & 12.8 \\
\hline 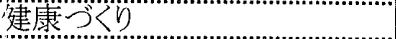 & 40.9 & 58.8 & 44.2 \\
\hline 高龄者対策 & 8.3 & 3.9 & 5.8 \\
\hline 過労死 & 0.8 & 5.9 & 2.3 \\
\hline 安全対策 & 5.3 & 3.9 & 7.0 \\
\hline 常勤以外苻業貝健康管理 & 0.0 & 2.0 & 1.2 \\
\hline 文の他 & 0.8 & 3.9 & 0.0 \\
\hline
\end{tabular}

